\title{
ENTRE NOSTALGIA E REDENÇÃO
}

Panorama de Michael Löwy aborda pontos de convergência entre filosofias judaico-alemãs do século XX

\author{
Luis S. Krausz* \\ Lowy, Michael \\ Judeus Heterodoxos: Messianismo, Romantismo, Utopia \\ Tradução de Marcio Honorio de Godoy \\ São Paulo, Perspectiva, 2012.
}

$\mathbf{N}$ a Europa de língua alemã dos séculos XIX e XX, o romantismo marcou a visão de mundo de filósofos, sociólogos e historiadores. Observando as sociedades industriais que rapidamente tornavam obsoletas formas de vida e de sociabilidade tradicionais, passou-se a criticar um modelo civilizatório onde as relações são pautadas não pela fé e pela confiança, mas pelo contrato e pelo cálculo, e onde o trabalho é rebaixado à condição de simples meio para o ganho. A revolta desses pensadores acompanha os desdobramentos da idolatria do progresso e dá-se em nome de valores culturais do passado, em especial da Idade Média. A nostalgia das eras pré-capitalistas ora toma a forma da melancolia ante o desencantamento do mundo, ora a de revolta, que conduz à formulação de utopias redencionistas.

Em Judeus Heterodoxos: Messianismo, Judaísmo e Utopia, Michael Löwy, professor da École des Hauts Études en Sciences Sociales de Paris, aborda alguns elos da corrente de pensadores que se formaram a partir da confluência entre a postura crítica do romantismo alemão e a tradição messiânica do judaísmo. Tratase de autores que, por meio de um convívio intenso, criaram uma constelação de utopistas e filósofos onde a estrela mais brilhante é Walter Benjamin, autor sempre atualíssimo, assunto de quatro dos doze capítulos deste volume, que foi concebido como uma espécie de continuação do já clássico Redenção e Utopia: o Judaísmo Libertário na Europa Central, (Cia. das Letras, 1989).

As origens do caráter profético e visionário da obra de Benjamin, da lucidez

\footnotetext{
* Professor doutor de Literatura Hebraica e Judaica da Faculdade de Filosofia, Letras e Ciências Humanas da USP; autor de Rituais Crepusculares: Joseph Roth e a Nostalgia Austro-Judaica (Edusp, 2008); Desterro: Memórias em Ruínas (Tordesilhas, 2011) e As Musas: Poesia e Divindade na Grécia Arcaica (Edusp, 2006).<lkrausz@uol.com.br>
} 
de suas visões que penetram como clarões no âmago das sociedades modernas, assim como da genialidade de sua escrita poética, são encontradas por Löwy na sensibilidade religiosa do misticismo judaico tanto quanto na démarche romântica em direção ao passado que, na Alemanha, significou um retorno à germanidade ancestral, à aristocracia e à cristandade medieval - esferas das quais os judeus estavam excluídos.

Deste paradoxo surge o interesse do filósofo por uma vertente judaica mística ausente do judaísmo alemão de seu tempo, reformado e moldado pelos parâmetros iluministas, e expurgado de seus ingredientes irracionais. Em busca de valores perdidos numa comunidade que buscava assimilar-se à modernidade burguesa, Benjamin aproximou-se do pensamento de Gershom Scholem e de Franz Rosenzweig, onde encontrou, no messianismo, um correspondente do Sturm und Drang (Tempestade e Ímpeto) românticos. O advento do reino messiânico passou a ser visto, então, como algo a ser preparado e antecipado pela humanidade - o que significou uma ruptura com as crenças estabelecidas e com os modelos de vida política de seu tempo.

A necessidade do despertar da humanidade do pesadelo da história é um dos aspectos que Löwy destaca nas afinidades eletivas entre Benjamin e Hannah Arendt, autora que compara o método heterodoxo de Benjamin ao de um pescador de pérolas a submergir nas profundezas para trazer à tona fragmentos preciosos de realidades sociais inconscientes. E também nas afinidades entre os pensamentos de Benjamin e de Gustav Landauer, para quem filosofia e reflexão social só têm significado na medida em que traduzidas em práxis, e que investiu a nostalgia das épocas pré-capitalistas com a esperança utópica de uma sociedade livre que, por sua vez, lhe parecia o cerne da mensagem bíblica.

Martin Buber, que saudou Landauer como "profeta da comunidade humana por vir," é abordado neste volume sob a ótica de sua militância no movimento Brit Schalom, ou "Aliança pela Paz", que, já na década de 1920, lutava pela ideia de que judeus e árabes deveriam trabalhar para um futuro comum no que era, então, a Palestina britânica. Também é destacada sua crítica das sociedades ocidentais modernas, em que os homens se tornaram extensões das máquinas, como autômatos em massas urbanas.

Já o messianismo heterodoxo de Gershom Scholem surge no contexto de um 
ressentimento contra o desencantamento do mundo e como busca, no mito, na história e na religião, de antídotos para a perda de sentido - não, porém, pela via de um retorno impossível ao passado e sim por meio de um reencantamento no interior da própria modernidade. Se Scholem toma a história como instrumento de ligação com o passado, ao mesmo tempo evidencia que a ideia de progresso e de aperfeiçoamento gradual da humanidade nada tem a ver com a tradição dos Profetas, que enfatiza o caráter intempestivo do advento da redenção.

Há, ainda, textos sobre Bernard Lazare e Manès Sperber, além da transcrição de uma entrevista do autor com Ernst Bloch, realizada em Tübingen, em 1974. Filosofia e reflexão religiosa surgem, aqui, não na forma de rarefeitos gases que pairam em aposentos acadêmicos, mas como guias de significado urgente e diretamente vinculado à realidade quotidiana. Talvez a maior das muitas virtudes desse livro seja seu poder de despertar o leitor para o que se passa à sua volta, aqui, agora. 